\title{
Performance evaluation of brewery biological wastewater treatment plant
}

\begin{abstract}
This study was conducted to evaluate the performance of biological treatment plant of a brewery located at Rajasthan, India. The biological treatment consists of anaerobic treatment through anaerobic hybrid reactor (AHR) and conventional aerobic treatment (Activated Sludge Process (ASP)). The results showed that the COD removal efficiencies ranged between $46.96 \%-89.71 \%$ for anaerobic treatment at an Organic Loading Rate of $0.9-3.6 \mathrm{~kg} \mathrm{COD} / \mathrm{m} 3 /$ day. The COD removal efficiency after aeration was in range of $12 \%$ to $74 \%$, making overall removal efficiencies of COD after Anaerobic (AHR) and Aerobic system to be between $75 \%$ to $97 \%$. This paper includes effluent characterization, treatment scheme and performance of a brewery ETP under study. In addition to it, the problems associated with the operation and maintenance of brewery Effluent Treatment Plant was discussed and suitable recommendations were made based on its performance.
\end{abstract}

Volume 3 Issue I - 2018

\author{
Mahesh Kothiyal,' GN Semwal' \\ 'Department of Civil Engineering, Lingaya's University, India \\ ${ }^{2}$ Envirolink Consultants, India \\ Correspondence: Mahesh Kothiyal, M. Tech Environmental \\ Engineering, Department of Civil Engineering, Lingaya's \\ University, Nachauli, Jasana Road, Old Faridabad, Haryana \\ I2 |002, India, Tel 9|-|29-259-820-0, \\ Email kothiyalmahesh@gmail.com
}

Received: November 15, 2017 | Published: January 10, 2018

Keywords: brewery, effluent treatment plant, BOD, COD, TDS, anaerobic hybrid reactor, activated sludge process

\section{Introduction}

Brewing is the process is for production of beer. ${ }^{1,2}$ It is said that for every 1 liter of beer production approximate 10 liters of water is used. ${ }^{3}$ The water in any brewery is typically used for brewing, rising and cooling process. ${ }^{3}$ The various steps that are involved in brewing process are malt production and handling, worth preparation, fermentation, filtration, CIP and finally packaging. ${ }^{1,4-6}$ The quality and quantity of effluent generated through various processes depend upon the water consumed in each process. ${ }^{4}$ Brewery effluent is characterized by high organic load and high acidic content., ${ }^{2,-10}$ It consists of soluble sugar, soluble starch, carbohydrates, ethanol, volatile fatty acid, suspended solids and yeast etc. ${ }^{3,6,11}$ Most of the organic present in brewery wastewater is biodegradable. COD to BOD ratios ranges from $1.5-$ 2.0. ${ }^{10,11}$ Several methods were used to treat the effluent generated from the brewery. Physical method is used to remove the coarse matter present in effluent. Chemical method can be employed to remove the suspended impurities. Biological treatment method like anaerobic and aerobic treatment results in removal of high COD and BOD present in wastewater. ${ }^{3,4}$ Wastewater from brewery doesn't contain adequate quantity of nitrogen required for biological oxidation due to which external nitrogen nutrients are required to be added into the aeration basins. ${ }^{11}$ Anaerobic, aerobic and reverse osmosis treatment provides better removal efficiency for brewery effluent. ${ }^{1,2}$ Bio-remediation methodology with anaerobic treatment can remove $90-98 \%$ of high COD present in brewery wastewater. Pseudomonas, gram negative bacteria has been found to act actively at a very high $\mathrm{pH}$, bringing $\mathrm{pH}$ down from 10.2 to $8.67 . .^{5}$ It has tested to reduce concentration of carbohydrates by $54 \%$ and proteins by $25 \%$ in brewery effluent The study of microbial consortia (Cronobacter sp. strain NGS4, Pseudomonas fluorescent NGS5, and Aeromonas sp. strain NGS7) with optimal oxygen flow (aeration), retention time and temperature showed reduction of COD by $67 \%$, BOD by $79 \%$ and TSS by $50 \% .^{12}$ The factors that affect the microbial ecology and characteristics of anaerobic reactors include Organic Loading Rate (OLR), Hydraulic Retention Time (HRT) and up low velocity. ${ }^{13}$ Anaerobic Hybrid Reactor (AHR) under thermophilic condition $\left(55^{\circ} \mathrm{C}\right)$ with an $5.5 \mathrm{~g}$
COD/ day OLR and 10 days HRT offered 90\% COD removal with high methane yield i.e.0.32 $\mathrm{g} \mathrm{CH}_{4} / \mathrm{g}$ COD removal was established through experimentation. ${ }^{14}$ Under mesophilic conditions $\left(35^{\circ} \mathrm{C}\right)$ high TCOD removals ranging between $42-86 \%$ at a OLRs of $0.5-24.0$ Kg COD m${ }^{-3} \mathrm{~d}^{-1}$ and HRT 4-6 hours were achieved through studies. ${ }^{13}$ Operational study for 2 years in Expanded Granular Sludge Bed reactor depicted $95 \%$ of COD conversion into gas and solid digestion with proper COD solubility and efficient EGSB mixing. ${ }^{13}$ 98\% COD, 99\% TSS and 98\% BOD removal rate were observed in brewery effluent treatment plant having UASB reactor followed by Sequential Batch Reactor (SBR). ${ }^{15}$ The advanced treatment technologies like SBR and membrane technologies provide an effective method of treating effluent. Additional advantage of latest technology is less power usage and reduction in plant footprint area. ${ }^{16}$ The comparative performance evaluation of aerobic treatment technologies on food industry effluent depicted highest BOD and COD reductions in case of fluidized aerobic biological reactor (FABR) than activated sludge process (ASP), stabilization pond and rotating biological contactors. The COD, BOD removal efficiencies through FABR was $85 \%$ and $91 \%$ respectively. ASP process showed $84 \%$ reduction in BOD and $90 \%$ reduction in COD. The reduction in case of Stabilization Pond and $\mathrm{RBC}$ was less than $79 \% .{ }^{17}$ Energy saving analysis at sewage treatment plant demonstrated that power consumption can be reduced by 7 to $17 \%$ by controlling settings for MLSS, Return Sludge Ratio and Rector Dissolved Oxygen. ${ }^{18}$ Reducing the water use and recycling the effluent are the two main factors that focus on the conservation of water. It will result in reduction of water and wastewater positively in brewery ${ }^{7}$ Stringent pollution control regulations, scarcity of fresh water and high cost of wastewater disposal has result in installation of Zero Liquid Discharge (ZLD) plants in past few decades..$^{19,20}$ ZLD system treats and recycles wastewater leaving no liquid discharge at the end. Reverse Osmosis, Ultra filtration, Evaporators etc form the part of zero discharge mechanism process. ZLD system reduces water pollution and increases water sustainability. ${ }^{19}$ Many ZLD systems have been installed in various breweries across globe to control the water pollution loads and recycle reuse the wastewater generated through the process. 


\section{Materials and methods}

Effluent Treatment Plant of a Brewery selected for study was located at Rajasthan, India. The data for the month of October was taken for the study starting from $1^{\text {st }}$ Oct'2016 to $31^{\text {st }}$ Oct'2016. The inlet and outlet characteristics were measured at particular point before and after each process unit. The sample for measuring the effluent characteristics was taken using sterilized plastic bottle of capacity one liter. Effective effluent management is the most important aspect in any industries. It improves the cost effectiveness of their production process also evade heavy discharge penalties. With growing crisis of ground and surface water in India, it has become imperative for major water intensive industries like brewery to introduce reuse/ recycling of treated effluent back into the process. The brewery effluent treatment plant under study has primary and secondary treatment facility (Figure $1)$.

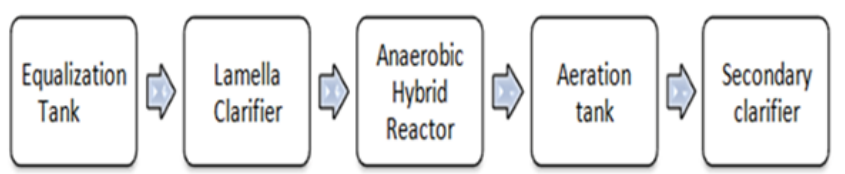

Figure I Process flow diagram of Brewery ETP understudy was as above:All parameters were analyzed in accordance with standard methods American Public Health Association.

\section{Results and discussion}

Equalization tank $\mathrm{pH}$ under study for a month ranges from 6.4 to 7.75. The quantity and quality of effluent is fluctuating (Figure 2).

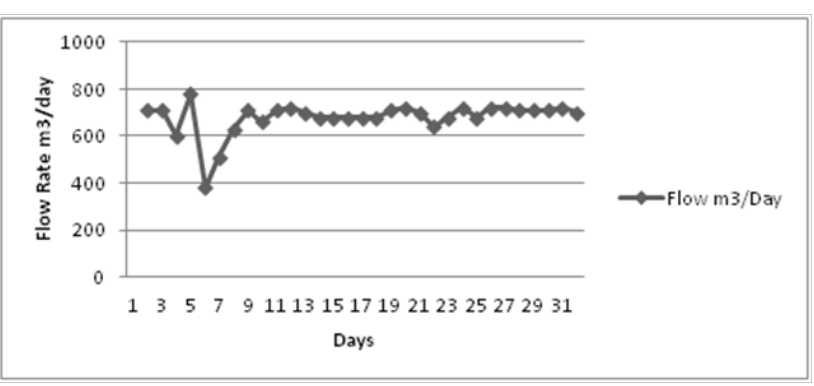

Figure 2 Graph of effluent flow rate $\left(\mathrm{m}^{3} /\right.$ day).

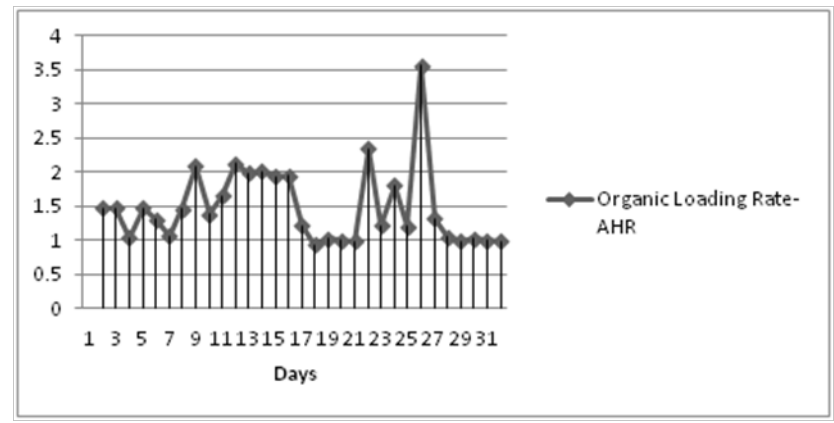

Figure 3 Organic Loading Rate (AHR) $\mathrm{Kg} C O D / \mathrm{m}^{3} / \mathrm{d}$.

\section{Performance of anaerobic hybrid reactor (AHR)}

The performance of anaerobic digestion is dependent on Organic loading, $\mathrm{C} / \mathrm{N}$ ratio, and the strength and amount of inoculum. Methanogenesis process is inhibited by an imbalanced Anaerobic Digestion caused by high organic loading and $\mathrm{C} / \mathrm{N}$ ratio, accumulation of VFA and low $\mathrm{pH}^{21}$ Anaerobic treatment method through AHR is used to remove overall COD and BOD. AHR or Anaerobic Hybrid Reactor is generally combination of suspended and attached growth process. It is very prevalent in high strength wastewater. COD of influent varies from $1241 \mathrm{mg} / \mathrm{l}-4460 \mathrm{mg} / \mathrm{l}$ in the month of October understudy. The Organic loading rate varies between $0.9-3.6 \mathrm{~kg}$ $\mathrm{COD} / \mathrm{m}^{3} /$ day. $\mathrm{pH}$ of the effluent also act as an important parameter in determining the functioning of digester. $\mathrm{pH}$ range between $6.4-7.6$ ensures normal functioning of digester. It is said that the methane forming bacteria are more sensitive to a slight changes in OLR, $\mathrm{pH}$ and Temperature as compared to the acid forming bacteria. More acid forming bacteria will result in excess volatile acids and thus upsets the digester. OLR ranging from $3.5-4.5 \mathrm{~kg} \mathrm{COD} / \mathrm{m}^{3} /$ day and $\mathrm{HRT}=2$ days, AHR has achieved the soluble COD removal efficiencies of 9799\% (Figures 3-5). ${ }^{22}$ A complex multi-biomass and multi- substrate process in which COD is decomposed firstly into volatile fatty acids (VFA) and after that into biogas, microbial biomass and residual matter is Anaerobic Digestion. ${ }^{23}$ VFA to total alkalinity ratio and bicarbonate alkalinity to total alkalinity ratio can predict the health of digesting system. It can provide early warning of process failure due to acidification of anaerobic digestion. ${ }^{24}$ The methane yield can be improved by reducing the particle size but excessive reduction may cause VFA accumulation. According to the studies conducted on food waste the optimum particle size for effective methane yield is $0.6 \mathrm{~mm}$. The VFA/ alkalinity ratio was determined using empirical formula to determine the risk of acidification..$^{25}$ The VFA to Total Alkalinity varies from $0.05-0.38$ during the one month duration of studies. Since, the VFA to alkalinity ratio is less than 4 , it indicates that the digester is stable. ${ }^{26}$ In other research studies conducted have shown that maximum concentration of biogas produced is at $8 \mathrm{~h}$ HRT, it corresponds to the favorable operating environment and good system stability ratio (VFA/Alkalinity) $<0.5$ achieved $^{27}$ (Figures $6 \& 7$ ). The COD removal efficiency was ranging from $46.96 \%-89.71 \%$. On a whole, we observed that the performance of the Anaerobic Hybrid Digester is satisfactory and the digester is stable.

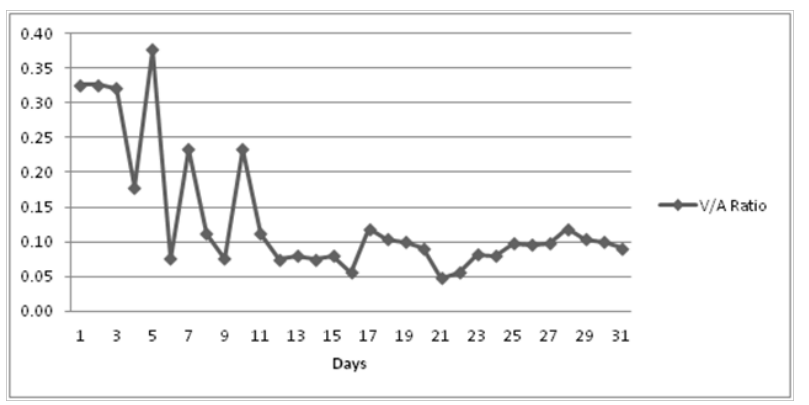

Figure 4 VFA/ Alkalinity Ratio.

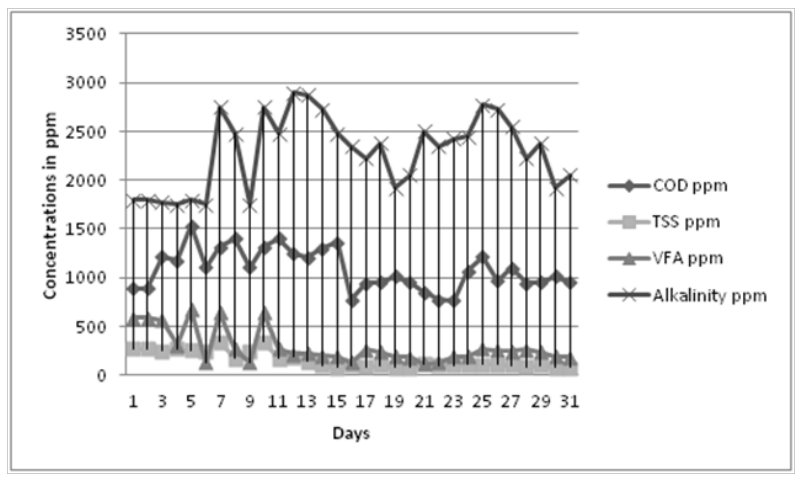

Figure 5 AHR Outlet Data. 


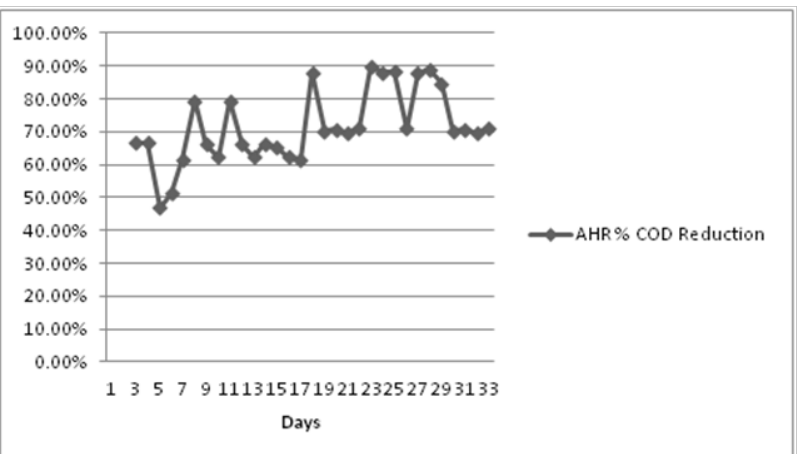

Figure $6 \%$ COD Reduction in AHR.

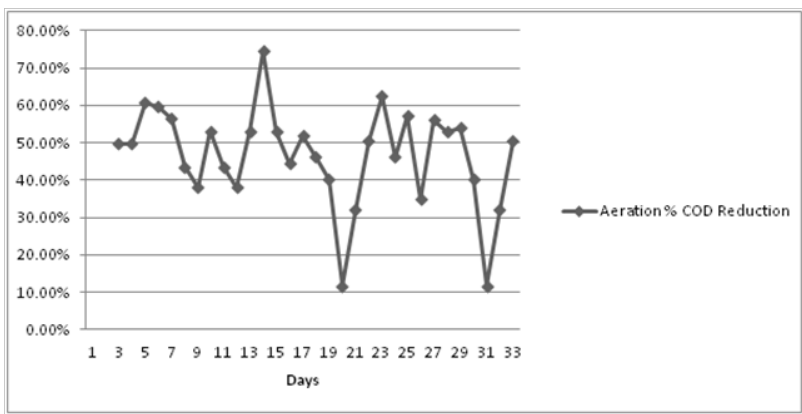

Figure 7 \% COD Reduction after Aeration.

\section{Performance of aeration process}

The $\mathrm{pH}$ ranged from 7.6 to 8.4. COD values gradually decreased from Aeration tank to Secondary Clarifier. The MLSS ranged from 3500 to $5700 \mathrm{mg} / \mathrm{L}$ in Aeration Tank-1 and 3200 to $5100 \mathrm{mg} / \mathrm{L}$ in Aeration Tank-2. COD removal was from $12 \%$ to $74 \%$ whereas it has less effect on TDS. Poor settling was observed at secondary clarifier. There are the fluctuations observed in the effluent load entering into the aeration basin due to which the treated outlet parameters are also fluctuating. The COD range at the outlet of secondary clarifier is from $67 \mathrm{mg} / \mathrm{L}-435 \mathrm{mg} / \mathrm{L}$ which is much more than that specified by pollution control board. COD removal efficiency is lowered with an increase in organic loading rate. Variation in the results can be controlled by maintaining the proper dissolved oxygen level in aeration basin. An ETP operator ensures enough oxygen in aeration tanks for microorganisms (typically $1.0-3.0 \mathrm{mg} / \mathrm{L}$ ) for optimal performance. ${ }^{28}$ It has been inferred from the research that for a higher strength wastewater attached growth process offers better performance. High specific surface area and low sludge production are the advantage of attached growth process (Figures $8 \& 9$ ). ${ }^{29}$

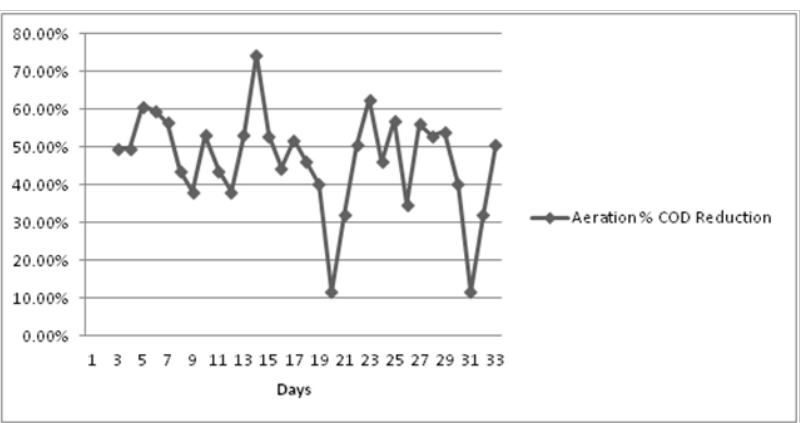

Figure 8 \% COD Reduction after Aeration.

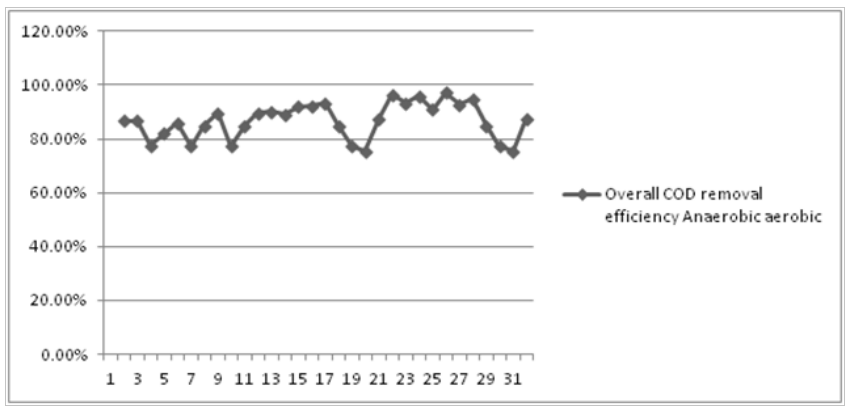

Figure $9 \%$ COD Reduction after Anaerobic and Aeration Treatment.

\section{Conclusion}

Brewery uses large volumes of water. The effluent generated in brewery is organic in nature and is easily biodegradable. Anaerobic system followed by aerobic proposes to be the most cost effective and efficient method of treatment. COD removal efficiency after Anaerobic (AHR) and Aerobic system was found to vary between $75 \%$ to $97 \%$ during the duration of study. To check stability of Anaerobic Hybrid Reactor close monitoring of VFA to total alkalinity should be done. VFA to Total Alkalinity should be less than 4 for a stable anaerobic system. Outlet parameters observed after treatment are not in line with the norms specified by Pollution control board in India. This is due to less effective aeration system. Aeration tanks should be sufficiently aerated so as to keep the biological content in suspended form. The dissolved oxygen level should be maintained $>1 \mathrm{ppm}$ at all levels. An attached growth process can also be adopted to improve aeration process efficiency. MLSS content should be in range of 3500-4500 $\mathrm{mg} / \mathrm{L}$, as excessive MLSS results in to drop of dissolved oxygen level and process is prone to bulking whereas less MLSS results in to loss of energy.

\section{Acknowledgements}

None.

\section{Conflicts of interest}

None.

\section{Funding}

None.

\section{References}

1. Chaitanyakumar D, Unnisa S, Rao B, et al. Efficiency assessment of combined treatment technologies:a casestudy of charminar brewery wastewater treatment plant. Indian Journal of Fundamental and Applied Life Sciences. 2011;1(2):138-145.

2. Beyene D, Rao PVV. The effectiveness of waste stabilization ponds in the treatment of brewery effluent the case of META ABO BREWERY waste stabilization ponds, Sebeta, Ethiopia. Abhinav National Monthly Refereed Journal of Research in Science \& Technology. 2013;2(8):1021.

3. Al- Rajhia S, Raut N, Al-Qasmi F, et al. Treatment of Industrials Wastewater by Using Microalgae. Paper presented in 2012 International Conference on Environmental, Biomedical and Biotechnology, IACSIT Press, Singapore. 2012;41:217-221.

4. World Bank. Industrial Pollution Prevention and Abatement:Breweries. Draft Technical Background Document. Environment Department, Washington, D.C. , USA; 1997. p. 272-274. 
5. Klijnhout AF, Van Eerde P. Centenary Review some characteristics of Brewery Effluent. Journal of the Institute of Brewing. 1986;92:426-434.

6. Akula L, Rao N, Habiulla S. Brewery Waste Water Treatment Using Sequential Batch Reactor:India. International Journal of Scientific Research. Environmental Science. 2014;3(10):32-35.

7. Brewers Association Water and Wastewater:Treatment/Volume Reduction Manual, India; p. 1-47.

8. Inyang UE, Bassey EN, Inyang JD. Characterization of Brewery Effluent Fluid. Journal of Engineering and Applied Sciences. 2012;4:67-77.

9. Simate G, Cluett J, Iyuke S, et al. Science Direct. Desalination, India; 2011. p. 235-247.

10. Enitan AM, Adeyemo J, Kumari S, et al. Characterization of Brewery Wastewater Composition. International Journal of Environmental, Chemical, Ecological, Geological and Geophysical Engineering. 2015;9(9):1036-1038.

11. Bodike R, Thatikonda S. Biotreatment of Brewary Effluent Using Pseudomonas Species. IOSR Journal of Environmental Science, Toxicology and Food Technology. 2014;8(6):08-12.

12. Anggraeni P, Gunam I, Kawuri R. Potential Bacterial Consortium to Increase the Effectiveness of Beer Wastewater Treatment. Current World Environment. 2014;9(2):312-320.

13. Jafarzadeh MT, Talebiazar L, Jamshidi N, et al. Performance evaluation of an anaerobic hybrid reactor treating petrochemical effluent Proceedings of the 2013 International Conference on Environment, Energy, Ecosystems and Development. 2013. pp. 99-106.

14. Wanitanukul S, Rukruem W, Chaiprasert P. Effect of Operating Condition on Performance of Anaerobic Hybrid Reactor at Thermophilic Temperature. Journal of Energy Technologies and Policy. 2013;3(11):211-219.

15. Radu T, Blanchard R, Smedley V, et al. Monitoring anaerobic digestion:a 2-year brewery case study. Journal of Environmental Engineering and Science. 2014;9(4):207-213.

16. Sharda AK, Sharma MP, Kumar S. Performance Evaluation of Brewery Waste Water Treatment Plant. International Journal of Engineering Practical Research (IJEPR). 2013;2(3):105-111.

17. Banwade N, Padigala B, Chattergee K. Comparative performance evaluation of aerobic treatment technologies on food industry effluent International Journal of Environmental Sciences. 2015;5(4):870-879.
18. Fukushima T, Somiya I, Inoue K, et al. Energy Saving Analysis at Sewage Treatment Plants -A Case study in China. Journal of Water and Environment Technology. 2013;11(4):275-286.

19. Tong T, Elimelech M. Critical Review on the Global Rise of Zero Liquid Discharge for Wastewater Management: Drivers, Technologies, and Future Directions. Environ Sci Technol. 2016;50(13):6846-6855.

20. Article on Outlook on Zero Liquid Discharge (ZLD) Market in India Frost \& Sullivan, India; 2013. p. 1-47.

21. Frigon JC, Guiot SR (2010) Biomethane production from starch and lignocellulosic crops: a comparative review. Biofuels Bioproducts Biorefining-Biofpr. 2013;4(4):447-458.

22. Wang L, Hung Y, Lo H, et al. Handbook of Industrial and Hazardous Wastes Treatment. CRC Press, India; 2004. p. 100-101.

23. Alcaraz-Gonzalez V, Fregoso-Sanchez F, Seyer J, et al. Exponential Regulation of Alkalinity and VFA in Continuous Anaerobic Digestion Processes under Uncertain Operational Conditions. WSEAS Transactions on Systems and Control. 2015;10:453-460.

24. Li L, He Q, Wei Y, et al. Early warning indicators for monitoring the process failure of anaerobic digestion system of food waste. Bioresource Technology. 2014;171:491-494.

25. Anderson GK, Yang G. Determination of bicarbonate and total volatile acid concentration in anaerobic digesters using a simple titration. Water Environment Research. 1992;64(1):53-59.

26. Pandey A, Singh P, Nigam N. Biotechnology for Agro Industrial Residues Utilization. Spinger Science \& Business Media. 2009;67-68.

27. Okonkwo PC, Aderemi BO, Okoli CS. Factors Affecting Biogas Production during Anaerobic Decomposition of Brewery effluentwastewater in a Fluidized Bed Digester. Journal of Environment and Earth Science. 2013;3(8):32-40.

28. Wisconsin Department of Natural Resources. Introduction to Activated Sludge Study Guide December Edition, India; 2010. p. 1-28.

29. Abdulgader ME, Yu QJ, Williams P, et al. A review of the performance of aerobic bioreactor for treatment of food processing wastewater. Proceedings of the Internatio nal Conference on Environmental Management, Engineering, Planning and Economics Skiathos, India; 2007. p. 1131-1136. 